\title{
EFFECT OF THE ADDITION OF NIOBIUM AND ALUMINIUM ON THE MICROSTRUCTURES AND MECHANICAL PROPERTIES OF MICRO-ALLOYED PM STEELS
}

\author{
VPLIV DODATKA NIOBIJA IN ALUMINIJA NA \\ MIKROSTRUKTURO IN MEHANSKE LASTNOSTI \\ MIKROLEGIRANIH PM JEKEL
}

\author{
Süleyman Gündüz ${ }^{1}$, Mehmet Akif Erden², Hasan Karabulut ${ }^{3}$, Mustafa Türkmen ${ }^{4}$ \\ ${ }^{1}$ Karabük University, Faculty of Technology, Department of Manufacturing Engineering, 78050 Karabük, Turkey \\ ${ }^{2}$ Karabük University, Institute of Science and Technology, Department of Manufacturing Engineering, 78050 Karabük, Turkey \\ ${ }^{3}$ Karabük University, Karabük Vocational School, 78050 Karabük, Turkey \\ ${ }^{4}$ Kocaeli University, Hereke Vocational School, Department of Metallurgy, Kocaeli, Turkey \\ hasankarabulut@karabuk.edu.tr
}

Prejem rokopisa - received: 2015-08-08; sprejem za objavo - accepted for publication: 2015-09-04

In this work, the effects of the addition of $\mathrm{Nb}$ and $\mathrm{Al}$ on the microstructures and tensile behaviours of micro-alloyed powder metallurgy (PM) steels were investigated. The microstructure of the micro-alloyed PM steels was examined by light microscope, SEM, XRD, XRF and EDS. The results indicated that the addition of $(0.1,0.15$ or 0.2$) \%$ of Nb-Al increases the yield strength $(Y S)$ and the ultimate tensile strength $(U T S)$ of the PM sintered steels. Elongation also tends to improve with an increasing Nb and $\mathrm{Al}$ content. In addition, the $\mathrm{Nb}$ and $\mathrm{Al}$ limit the grain growth during austenitization.

Keywords: powder metallurgy, micro-alloyed steels, microstructure

$\mathrm{V}$ delu je bil preiskovan vpliv dodatka $\mathrm{Nb}$ in $\mathrm{Al}$ na mikrostrukturo in na natezno trdnost mikrolegiranih PM jekel, izdelanih iz prahov. Mikrostruktura mikrolegiranih PM jekel je bila preiskovana s svetlobnim mikroskopom ter s SEM, XRD, XRF in EDS. Rezultati so pokazali, da dodatek $(0,1,0,15$ ali 0,2$) \%$ Nb-Al poveča mejo plastičnosti $(Y S)$ in natezno trdnost (UTS) sintranih $\mathrm{PM}$ jekel. Tudi raztezek se izboljša s povečano vsebnostjo $\mathrm{Nb}$ in Al. Ugotovljeno je še, da dodatek Nb in $\mathrm{Al}$ omejuje rast zrn med avstenitizacijo.

Ključne besede: metalurgija prahov, mikrolegirana jekla, mikrostruktura

\section{INTRODUCTION}

Steels with a minimal strength high toughness and excellent weldability are required in a wide range of applications. This combination of properties is achieved by optimizing the chemical composition and by thermomechanical processing (TMP). The addition of microalloying elements such as $\mathrm{Nb}, \mathrm{V}, \mathrm{Ti}$ and $\mathrm{Al}$ contribute to an increase in strength, both directly, through microstructural refinement and precipitation strengthening, and indirectly, through enhanced hardenability and an associated modification of the transformation microstructure. ${ }^{1-3}$

Niobium forms nitrides and carbides, but it is the carbide that is the most important. In steels it precipitates at a temperature just below $1000{ }^{\circ} \mathrm{C}$ and prevents austenite recrystallization. Niobium carbide particles are very effective in preventing austenite recrystallization and the formation of "pancake" grains that transform to fine ferrite grains. ${ }^{4-6}$ Thus, the precipitation of niobium carbide particles plays a major role in controlling the final microstructure and the product properties. Besides increasing the non-recrystallization temperature, the presence of precipitates also increases the austenite grain- coarsening temperature ${ }^{7}$, which is important through controlled reheating. ${ }^{8}$ Niobium is widely used in this way for the production of fined-grained pipeline and other structural steels.

A large volume of work was spent investigating the effect of niobium on the recrystallization and growth of austenite grains, ${ }^{5,6,9,10}$ and it was found that a minor addition of niobium to the steel was sufficient to inhibit the static recrystallization of austenite and to achieve the final microstructure. ${ }^{11}$ Similar effects were observed in titanium, and vanadium steels were found generally less marked. ${ }^{12}$

Aluminium only forms nitride precipitates, which are stable at temperatures above $900{ }^{\circ} \mathrm{C}$. It forms during reheating to heat-treatment temperatures and at the expense of the vanadium nitride, if present. At normalising temperatures it is stable, pins grain boundaries and is effective in refining the grain size. ${ }^{12}$ Aluminium nitride forms only with a hexagonal crystal lattice and it was not found in any substantial solid solution in the face-centred-cubic micro-alloy carbonitrides. ${ }^{4}$

AlN precipitation occurs at both grain boundaries and dislocations. It has been shown that the precipitation kinetics depends on the content of nitrogen and alumi- 

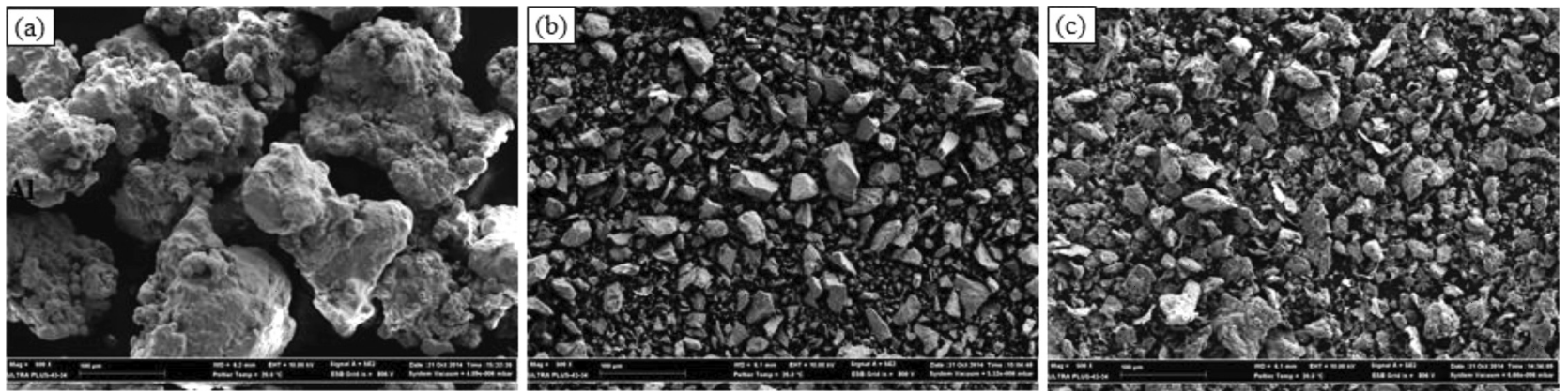

Figure 1: SEM micrographs of $\mathrm{Fe}, \mathrm{Nb}$ and $\mathrm{Al}$ powders: a) $\mathrm{Fe} \leq 180 \mu \mathrm{m}$, b) $\mathrm{Nb}<45 \mu \mathrm{m}$ and c) $\mathrm{Al}<75 \mu \mathrm{m}$

Slika 1: SEM-posnetki prahov $\mathrm{Fe}, \mathrm{Nb}$ in $\mathrm{Al}$ : a) $\mathrm{Fe} \leq 180 \mu \mathrm{m}$, b) $\mathrm{Nb}<45 \mu \mathrm{m}$ in c) $\mathrm{Al}<75 \mu \mathrm{m}$

nium in the steel and also on the grain size and the annealing temperature. ${ }^{13}$ In the austenite region, the precipitation occurs predominantly at the grain boundaries because of the considerable volumetric misfit of the AlN precipitates and the steel matrix, ${ }^{14}$ and the increased diffusion rate of both elements at the grain boundaries, as compared to the grains. ${ }^{15}$

The rising costs and disposition volatility of metals has led to the development of new PM steels. In particular, PM steels with the addition of copper, nickel and molybdenum to compete with wrought grades. Recently, due to cost constraints and availability, PM steels have also included chromium and manganese as the alloying elements. These material systems are categorized as alloy steels, since significant levels of these elements are required to achieve changes in the mechanical properties. ${ }^{16}$ The demand for cheaper but highstrength structural steels forced powder metallurgists to seek newer compositions with wider applications, and such steels found applications in the automotive industry, aerospace, and power tools. ${ }^{17}$

Micro-alloyed steels contain small amounts of niobium, vanadium or titanium, generally at levels between 0.02 and $0.2 \%$ of mass fractions. Despite the low alloy content, micro-alloying can lead to a major increase in the strength and toughness as a result of carbonitride particles, which led to precipitation strengthening and grain refinement. ${ }^{16}$ The production of micro-alloyed steels is estimated to be around $12 \%$ of the total world steel production and are used in every major steel market sector. In many parts of the world their development has played an important role in the expansion of some key industries, such as oil and gas extraction, construction, and transportation. ${ }^{18}$ The present study was undertaken to

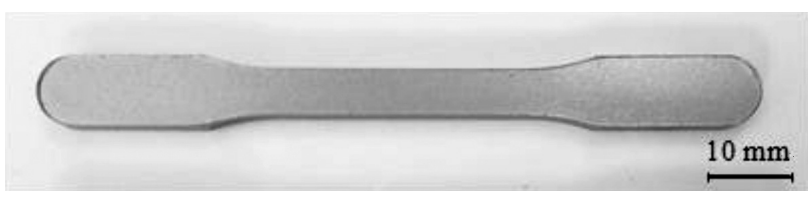

Figure 2: General view of tensile test specimen sintered at $1350{ }^{\circ} \mathrm{C}$ for $1 \mathrm{~h}$

Slika 2: Izgled preizkušanca za natezni preizkus, $1 \mathrm{~h}$ sintranega na $1350{ }^{\circ} \mathrm{C}$ examine the effect of $\mathrm{Nb}$ and $\mathrm{Al}$ on the microstructure and mechanical properties of sintered PM steels. The mechanical properties were determined and the microstructures were investigated in the sintered condition to assess the role of precipitation strengthening and grain refinement.

\section{MATERIALS AND EXPERIMENTAL PROCEDURE}

In this investigation, $\mathrm{Fe}, \mathrm{Nb}$ and $\mathrm{Al}$ powders of $\leq 180$ $\mu \mathrm{m},<45 \mu \mathrm{m}$, and $<75 \mu \mathrm{m}$ supplied by Aldrich were used, with purities of $99.9 \%, 99.8 \%$ and $93 \%$, respectively. Electron micrographs of the powders presented in Figure 1 reveal an irregular shape of the powder particles for all the studied samples. The required mass of Fe-0.25C (Alloy 1), Fe-0.25C-0.05Nb-0.05Al (Alloy 2), $\mathrm{Fe}-0.25 \mathrm{C}-0.075 \mathrm{Nb}-0.075 \mathrm{Al}$ (Alloy 3) and Fe-0.25C$0.1 \mathrm{Nb}-0.1 \mathrm{Al}$ (Alloy 4 ) powders was accurately weighed and mixed in an industrial conic mixer for $1 \mathrm{~h}$. A total of 0.45 of graphite was added to reach a carbon content of $0.25 \%$ in the sintered test pieces. Zn-stearate was added as a lubricant. The mixed powder mass was then compacted into dog-bone tensile specimens using a hydraulic press with a capacity of 100 tons and a compaction pressure of $700 \mathrm{MPa}$. Standard cross-section tensile-test specimens were produced in accordance with the standard of ASTM E8/E8M ${ }^{19}$ as shown in Figure 2. The specimen has two large shoulders with a smaller cross-section gauge in between. The shoulders are large so they can be readily gripped, whereas the gauge section has a smaller cross-section.

The test pieces were sintered in a tube furnace with an argon atmosphere. The sintering cycle was: heating to $1350{ }^{\circ} \mathrm{C}$ at a rate of $5^{\circ} \mathrm{C} / \mathrm{min}$, holding at this temperature for $1 \mathrm{~h}$, cooling to room temperature at a rate of $5{ }^{\circ} \mathrm{C} / \mathrm{min}$. The sintered density was determined by Archimedes' principle using pure water according to ASTM B 328-96.20 Four measurements were made for each composition and the variation of those values was less than $1 \%$. A tensile test at room temperature was performed using a Schimadzu tensile-testing machine at

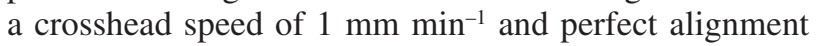
of the specimens in the pull direction and no slippage. 
Three specimens of each alloy were tested and the mean value was used.

The examination of the microstructure was carried out using optical and scanning electron microscopy (SEM), and energy-dispersive spectrometry (EDS) was used to provide elemental analyses of the particles. The average elemental composition of alloys was determined with the X-ray fluorescence technique (XRF). The chemical composition of the produced PM steels is presented in Table 1. The specimens were mechanically polished using a standard metallographic procedure and etched with $2 \%$ Nital solution. The microstructures were examined in a Nikon ECLIPSE L150 microscope with a magnification of $50 \times$ to $1000 \times$. An electrochemical extraction technique was used to characterise the precipitates in the examined specimens. This procedure involves the electrochemical dissolution of tensile specimen in the electrolyte $(10 \% \mathrm{HCl}$ in methanol) and filtering to separate the precipitate from the solution. The dissolution time of 8 hours sufficed for the dissolution of around two grams of the specimen. For the filtering, cellulose acetate filters were used with a pore size of 0.4 $\mu \mathrm{m}$ and X-ray diffraction (XRD) analysis of the collected residues with precipitates was carried out. The XRD data were obtained using $\mathrm{Cu}-K_{\alpha}$ radiation, a scan step of $4^{\circ}$, a step time of $1 \mathrm{~min}$ and $2 \theta$ range from $20^{\circ}$ to $90^{\circ}$.

Table 1: Chemical composition of PM steel and microalloyed PM steels

Tabela 1: Kemijska sestava PM jekla in mikrolegiranih PM jekel

\begin{tabular}{|l|c|c|c|c|c|}
\hline & $\mathrm{Fe}$ & $\mathrm{C}$ & $\mathrm{Mn}$ & $\mathrm{Al}$ & $\mathrm{Nb}$ \\
\hline Alloy 1 & 99.232 & 0.249 & 0.2110 & 0.0000 & 0.0000 \\
\hline Alloy 2 & 98,5174 & 0.2355 & 0.2316 & 0.0514 & 0.0468 \\
\hline Alloy 3 & 99.0191 & 0.2624 & 0.2223 & 0.0752 & 0.0740 \\
\hline Alloy 4 & 99.0452 & 0.2653 & 0.2223 & 0.0974 & 0.0918 \\
\hline
\end{tabular}

The grain size measurement was carried out using the mean linear intercept (mli) method, with the line inclined by $45^{\circ}$. At least 500 grains cut by the intersecting line were counted for each sample. From the results the mean linear intercept grain sizes ${ }^{21,22}$ was determined. The statistical errors for the assessment of the mean linear intercept were examined by Woodhead and reviewed by J. R. Blank and T. Gladman, ${ }^{23}$ and it was suggested that the relative error of the individual intercept value $\left(\sigma_{i} / i\right)=$ 0.7 is almost constant for a variety of regular and spacefilling polyhedrals. The relative error, $\phi$, of the mean linear intercept based on the measurement of $n$ grains $\left(S E_{i} / i\right)$ is deduced as shown in Equation (1):

$$
f=\frac{S E_{i}}{i}=\frac{\frac{\sigma_{i}}{\iota}}{\sqrt{n}}=\frac{0.7}{\sqrt{n}}
$$

where $\sigma_{i}$ is the standard deviation of the assessment of the intercept lengths.

The volume fraction of ferrite or pearlite was also calculated using the systematic point-count method..$^{24,25}$ According to this method, when the grid points intersect the ferrite boundary, they are counted as half. Errors in the point counting were also calculated by T. Gladman and J. Woodhead ${ }^{26}$ in Equation (2):

$$
\sigma=\sqrt{\frac{f(1-f)}{N}}
$$

where $\sigma$ is the standard deviation, $f$ is the measured volume fraction of ferrite or pearlite and $N$ is the total number of points counted. All the volume fractions were expressed $\pm \sigma$ (standard deviation)

\section{RESULTS AND DISCUSSION}

The light micrographs of the Fe-0.25C (Alloy 1), Fe-0.25C-0.05Nb-0.05Al (Alloy 2), Fe-0.25C-0.075Nb$0.075 \mathrm{Al}$ (Alloy 3) and Fe-0.25C-0.1Nb-0.1Al (Alloy 4) $\mathrm{PM}$ steel in Figure 3 show that the microstructures of the examined steels consist of ferrite and pearlite grains of varying sizes. In Table 2 the relative density, phase volume fractions and mean linear intercept grain sizes of the specimens are listed.

Figure $\mathbf{3}$ and the data in Table $\mathbf{2}$ indicate the grain sizes decreasing with an increasing content of $\mathrm{Nb}-\mathrm{Al}$, from $0.1,0.15$ or $0.2 \%$. A major benefit of micro-alloying is the decrease of the grain growth rate during

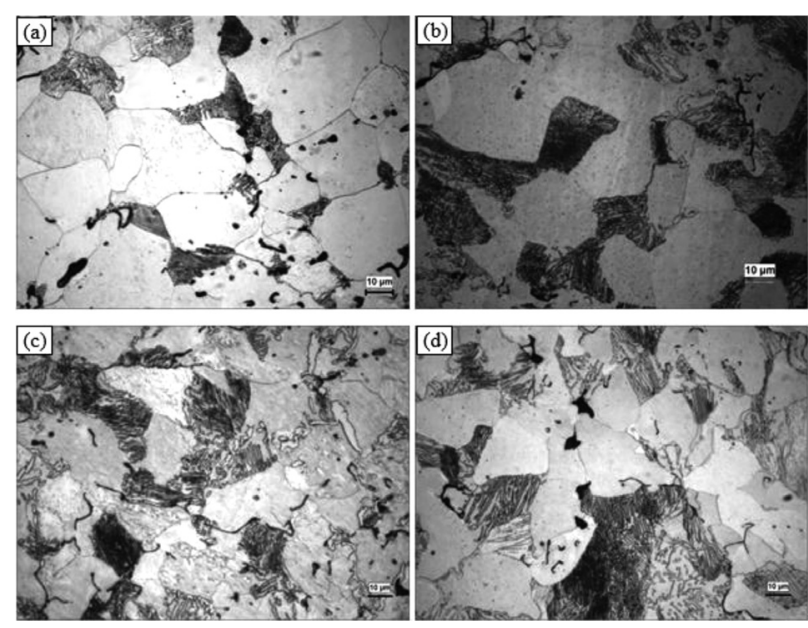

Figure 3: Microstructures of sintered PM steel and microalloyed PM steels: a) Alloy 1, b) Alloy 2, c) Alloy 3, and d) Alloy 4

Slika 3: Mikrostrukture sintranega PM jekla in mikrolegiranih PM jekel: a) zlitina 1, b) zlitina 2, c) zlitina 3 in d) zlitina 4

Table 2: Relative density, mean linear intercept grain sizes and volume fractions of ferrite and pearlite phases in the PM steel and microalloyed PM steels

Tabela 2: Relativna gostota, srednja velikost zrn pri linearni intercepciji in volumenski delež ferita in perlita v PM jeklu in v PM mikrolegiranem jeklu

\begin{tabular}{|c|c|c|c|c|}
\hline Alloy & $\begin{array}{c}\text { Relative } \\
\text { density }(\%)\end{array}$ & $\begin{array}{c}\text { Grain size } \\
(\mu \mathrm{m})\end{array}$ & $\begin{array}{c}\text { Ferrite } \\
(\%)\end{array}$ & $\begin{array}{c}\text { Pearlite } \\
(\%)\end{array}$ \\
\hline Alloy 1 & 92 & $29.7 \pm 0.93$ & $78.4 \pm 0.018$ & $21.6 \pm 0.018$ \\
\hline Alloy 2 & 94 & $27.2 \pm 0.85$ & $75 \pm 0.019$ & $25 \pm 0.019$ \\
\hline Alloy 3 & 94 & $23.4 \pm 0.73$ & $74 \pm 0.02$ & $26 \pm 0.019$ \\
\hline Alloy 4 & 94 & $22.9 \pm 0.71$ & $73 \pm 0.02$ & $27 \pm 0.02$ \\
\hline
\end{tabular}


austenitizing, and if fine precipitates exist during austentizing the growth of grains is restricted and a finer grain size is obtained after quenching. ${ }^{16,27}$ Niobium has a low solubility product that allows the substantial dissolution of niobium carbonitrides only at elevated temperatures. At low temperatures in the austenite range, the carbonitride shows such low solubility and the dispersion strengthening is not generally observed. The undissolved carbonitride at these temperatures acts mostly as an effective grain refiner. The marked change in carbonitride dissolution between the high and low temperatures $\left(1300{ }^{\circ} \mathrm{C}\right.$ and $\left.900{ }^{\circ} \mathrm{C}\right)$ in the austenite temperature range allows substantial strain-accelerated precipitation at temperatures below about $1000{ }^{\circ} \mathrm{C}$, and produces what is arguably the most obvious distinctive effect of niobium, i.e., the marked retardation of recrystallization at these temperatures. , $28-30^{-}$

Aluminium only forms a nitride that is stable at low temperatures in the austenite range, but will dissolve progressively as the temperature is increased. The extent of the dissolution at high temperatures in the austenite range (e.g. $1350{ }^{\circ} \mathrm{C}$ ) depends upon the content of aluminium and nitrogen, but the solubility product for aluminium nitride is low and the only common micro-alloy nitride having a lower solubility product is titanium nitride. Aluminium nitride has the distinction of forming a separate nitride, which has a hexagonal crystal structure and forms no solid solution with the face-centredcubic micro-alloy carbonitrides. ${ }^{12}$

Table 3 shows the yield strength $(Y S)$, ultimate tensile strength (UTS) and elongation of the examined PM steels, and Figure 4 shows typical examples of the stress-strain curves obtained with the tensile test and a general increase of $Y S$ and UTS of steel with the addition of $\mathrm{Nb}$ and $\mathrm{Al}$. Elongation tends to improve with increasing $\mathrm{Nb}-\mathrm{Al}$ content. These changes are a consequence of the differences in the precipitation distribution. ${ }^{31}$ High strength and good toughness in micro-alloyed steels are

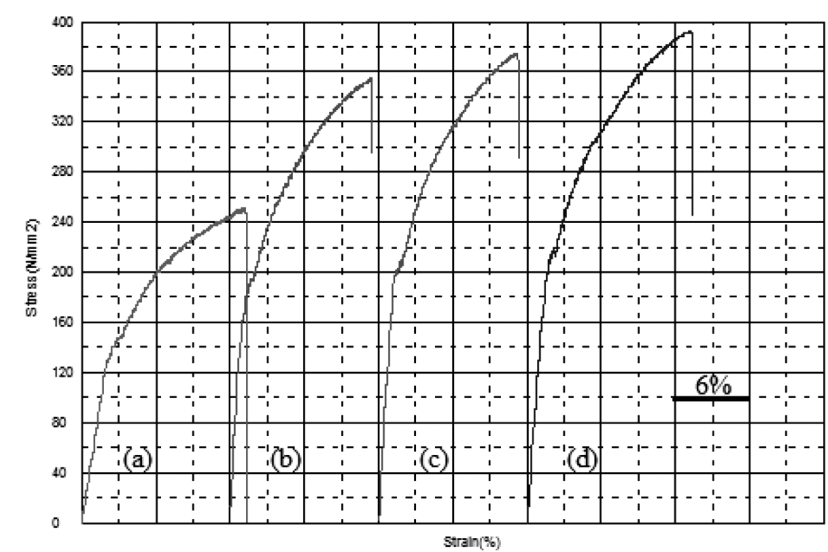

Figure 4: Variation of stress-strain curves of the PM steel and microalloyed PM steels at different percentages of $\mathrm{Nb}$ and $\mathrm{Al}$ content: a) Alloy 1, b) Alloy 2, c) Alloy 3, and d) Alloy 4

Slika 4: Spreminjanje krivulj napetost-raztezek PM jekla in mikrolegiranih PM jekel pri različnih vsebnostih $\mathrm{Nb}$ in $\mathrm{Al}$ : a) zlitina 1, b) zlitina 2, c) zlitina 3 in d) zlitina 4 achieved by a combination of micro-alloying and controlled rolling. During sintering and slow cooling from the sintering temperature $\mathrm{NbC}(\mathrm{N})$ or $\mathrm{AlN}$ precipitates form in the austenite and the ferrite during the austeniteferrite transformation or after transformation, as suggested by M. A. Erden at al. ${ }^{32}$ These lead to an increase in the strength compared with the titanium-free alloy.

Table 3: Mechanical properties of sintered PM steel and microalloyed PM steels

Tabela 3: Mehanske lastnosti sintranega PM jekla in mikrolegiranih PM jekel

\begin{tabular}{|c|c|c|c|}
\hline Alloy & $\begin{array}{c}\text { Yield strength } \\
(\mathrm{MPa})\end{array}$ & $\begin{array}{c}\text { Ultimate tensile } \\
\text { strength }(\mathrm{MPa})\end{array}$ & $\begin{array}{c}\text { Elongation } \\
(\%)\end{array}$ \\
\hline Alloy 1 & 144 & 252 & 13 \\
\hline Alloy 2 & 198 & 356 & 12 \\
\hline Alloy 3 & 209 & 375 & 12 \\
\hline Alloy 4 & 220 & 394 & 13 \\
\hline
\end{tabular}

The alloying elements have widely differing effects due to the different solubilities of their carbides and nitrides in both austenite and ferrite as well as their different precipitation kinetics. The strength is increased by grain refinement and precipitation hardening, by a sufficient content of carbon and nitrogen in the steel. ${ }^{33,34}$ In modern micro-alloyed steels, the requirements for specific properties may call for the use of more than one micro-alloying element. An example are Al-Nb steels, where aluminium is used for the grain refinement and niobium for controlling the hot-rolled microstructure and dispersion strengthening. The behaviour of the microalloying elements can be modified by the presence of another of them and changes dependent on the particular elements. In principle, it depends on their mutual insolubility or mutual solubility. AlN has a close-packed-hexagonal structure, with little or no solubility for niobium and the $\mathrm{NbN}$ has a cubic structure with little or no solubility for aluminium. Under these conditions, the two separate nitrides can co-exist in the austenite according to their own solubility products. ${ }^{35}$

In the present experimental work, the solubility product of $\mathrm{AlN}, \mathrm{NbN}$ and $\mathrm{NbC}$ at $1350{ }^{\circ} \mathrm{C}$ was calculated using the equations given by K. Narita. ${ }^{36}$ At $1350{ }^{\circ} \mathrm{C}$ the solubility products of $\mathrm{AlN}, \mathrm{NbN}$ and $\mathrm{NbC}$ are $2.3 \times 10^{-3}$, $3.7 \times 10^{-3}$ and $3.6 \times 10^{-2}$. It is clear that the solubility of $\mathrm{NbC}$ is higher than $\mathrm{NbN}$ and $\mathrm{AlN}$, and therefore niobium and carbon atoms should be present in the solid solution during sintering at $1350{ }^{\circ} \mathrm{C}$. The dissolved $\mathrm{Nb}$ will precipitate as $\mathrm{NbC}(\mathrm{N})$ in austenite or ferrite, depending on the cooling rate. The strength increment in microalloyed PM steels is mainly due to precipitation hardening, resulting in the formation of $\mathrm{AlN}$ and $\mathrm{NbC}(\mathrm{N})$.

The steel's mechanical properties and toughness were analysed in terms of the influence of grain size. Traditionally, the approaches developed by E. O. Hall ${ }^{37}$, based on experimental observations, and by N. S. Petch, ${ }^{38}$ based on both experimental and theoretical approaches. 
The relation between the yield strength and the grain size is now commonly known as the Hall-Petch equation (3):

$$
\sigma_{y}=\sigma_{0}+k_{y} d^{-1 / 2}
$$

where $\sigma_{y}$ is the lower yield stress, $\sigma_{\mathrm{o}}$ is the friction stress, $k_{y}$ is the strengthening coefficient and $d$ is the grain size. To study the influence of precipitates and clusters on the strength of micro-alloyed PM steel it is necessary to calculate the value of $\sigma_{\mathrm{p}}$, which represents the strength obtained from precipitates and clusters in the micro-alloyed PM steel containing a different weight percentage of $\mathrm{Nb}-\mathrm{Al}$. This was done using the F. B. Pickering and T. Gladman ${ }^{39}$ equation (4):

$$
\sigma_{y}=54+17.4 d^{-1 / 2}+\sigma_{p}
$$

where $d$ is the grain diameter in $\mathrm{mm}$, and $\sigma_{\mathrm{p}}$ is the strength obtained from precipitates and clusters. In the present study the $\sigma_{\mathrm{p}}$ values were calculated using equation (2) for micro-alloyed PM steels. A value for the level of $\sigma_{\mathrm{p}}$ was derived by subtracting the predicted yield strength from the actual yield strength. The values of $\sigma_{\mathrm{p}}$ are given in Table 4 and vary from -10 to $51 \mathrm{MPa}$ for the $\mathrm{Nb}$-Al-free and $\mathrm{Nb}$-Al-added micro-alloyed PM steels tensile tested at room temperature.

As seen in Table 4, different values for $\sigma_{\mathrm{p}}$ were observed in the PM steel and microalloyed PM steels. For example, the additions $(0.1,0.15$ and 0.2$)$ of $\mathrm{Nb}-\mathrm{Al}$ increased the precipitation contribution $\left(\sigma_{\mathrm{p}}\right)$. This is a result of the formation of carbonitrides after sintering at $1350{ }^{\circ} \mathrm{C}$, which led to both precipitation strengthening and grain refinement. Alloy 1 without $\mathrm{Nb}-\mathrm{Al}$ does not

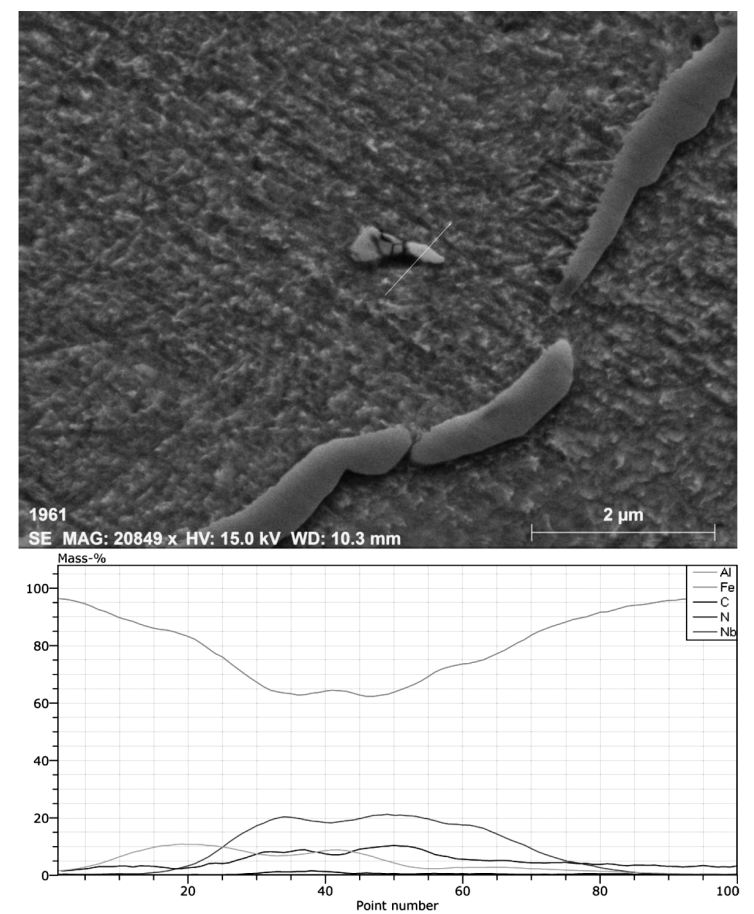

Figure 5: SEM micrograph for Alloy 2 and EDS line scan of the indicated particle

Slika 5: SEM-posnetek zlitine 2 in EDS-analiza preko označenega delca show any measurable precipitation strengthening. The role of niobium in sintered PM steels was investigated by several investigators. ${ }^{40-43}$ To examine this effect a simple iron-carbon system was investigated by $0.16 \%$ of mass fractions of $\mathrm{Nb}$ and carbon contents from 0.10 to $0.50 \%$ of mass fractions and transverse rupture strength and apparent hardness were measured in the sintered condition. At low carbon there is an increase in the transverse rupture strength, presumably due to the precipitation of $\mathrm{NbC}(\mathrm{N})$. The precipitation of nitrides, as AlN may also occur during sintering and/or cooling after sintering, since nitrogen cannot be completely avoided in PM steels using current sintering technologies, such as sintering under an argon atmosphere. It has been shown that the $\gamma \rightarrow \gamma+\alpha$ transformation in isothermal conditions accelerates the precipitation kinetics of $\mathrm{AlN}$, due to the lower solubility of nitrogen in ferrite. ${ }^{44}$

Table 4: Structure-property analyses of PM steel and microalloyed PM steels tensile tested at room temperature

Tabela 4: Analiza lastnosti PM jekla in mikrolegiranih PM jekel pri nateznem preizkusu na sobni temperaturi

\begin{tabular}{|l|c|c|c|c|c|c|}
\hline Alloy & $\begin{array}{c}\sigma_{\mathrm{o}} \\
(\mathrm{MPa})\end{array}$ & $d(\mu \mathrm{m})$ & $\begin{array}{c}k_{y} d^{-1 / 2} \\
(\mathrm{MPa})\end{array}$ & $\begin{array}{c}\sigma_{\mathrm{y}} \text { total } \\
(\mathrm{MPa})\end{array}$ & $\begin{array}{c}\sigma_{y} \text { test } \\
(\mathrm{MPa})\end{array}$ & $\begin{array}{c}\sigma_{\mathrm{p}} \\
(\mathrm{MPa})\end{array}$ \\
\hline Alloy 1 & 54 & $29.7 \pm 0.93$ & 100 & 154 & 144 & -10 \\
\hline Alloy 2 & 54 & $27.2 \pm 0.85$ & 106 & 160 & 198 & 38 \\
\hline Alloy 3 & 54 & $23.4 \pm 0.73$ & 113 & 167 & 209 & 42 \\
\hline Alloy 4 & 54 & $22.9 \pm 0.71$ & 115 & 169 & 220 & 51 \\
\hline
\end{tabular}

$\sigma_{\mathrm{o}}$ : the friction stress, $d$ : grain size, $k_{y}$ : strengthening coefficient, $\sigma_{y}$ total: predicted yield strength, $\sigma_{y}$ test: actual yield strength, $\sigma_{\mathrm{p}}$ : difference between predicted yield strength and actual yield strength (strength obtained from precipitates)

The density is also expected to significantly affect the properties of PM steel and micro-alloyed PM steels because the pores are potential crack-initiation sites, and can also guide and propagate cracks through the material. This reduces the strength as well as the heat-transfer and cooling rates after sintering. ${ }^{45} \mathrm{~A}$ strong microstructure may be obtained by incorporating small amounts of alloying elements to compensate for the effect of pores. ${ }^{46}$
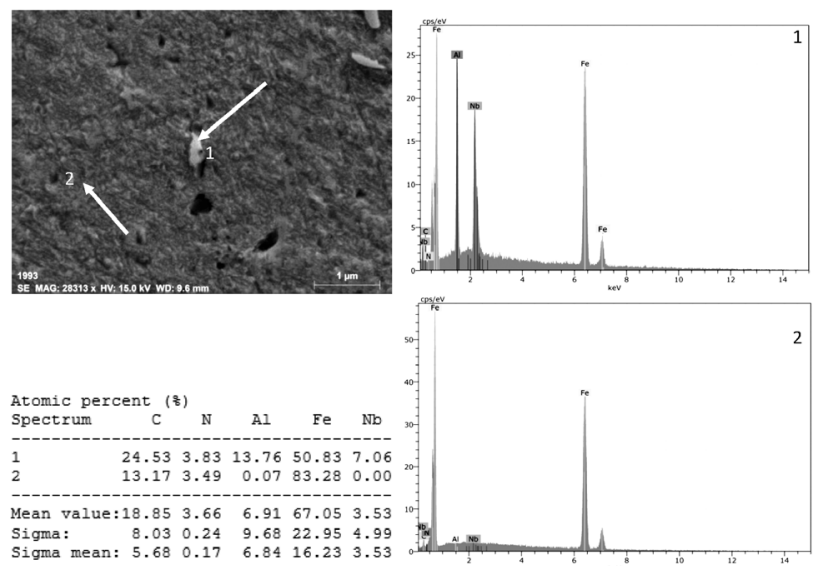

Figure 6: SEM micrograph for Alloy 4 and corresponding EDS of the indicated points

Slika 6: SEM-posnetek zlitine 4 in EDS-analiza označenih točk 
In the present work PM steel and micro-alloyed PM steels showed a similar relative density, i.e., $92 \%$ and $94 \%$, for the as-sintered condition. This may explain that the strength increase is the effect of the different content of $\mathrm{NbC}(\mathrm{N})$, AlN in micro-alloyed PM steel.

Figure 5 illustrates $\mathrm{EDS} \mathrm{Fe}, \mathrm{Nb}$ and $\mathrm{C}$ line analysis of the cross-section of the matrix and precipitate particle in Alloy 2 (Fe-0.25C-0.05Nb-0.05Al). Two distinct constituents are detectable: a Fe-rich matrix and a $\mathrm{Nb}$-rich phase depicted a sharp increase from the Fe-rich matrix to the particle and inverse Fe behaviour. Figure 6 also shows EDS analyses at points of 1 (precipitate particles) and 2 (matrix) marked in the micrograph of Alloy 4 $(\mathrm{Fe}-0.25 \mathrm{C}-0.1 \mathrm{Nb}-0.1 \mathrm{Al})$. As seen in Figure 6, at point 1 the $\mathrm{Fe}, \mathrm{C}, \mathrm{N}, \mathrm{Al}, \mathrm{Nb}$ and at point 3 the $\mathrm{Fe}, \mathrm{C}, \mathrm{N}$ contents are detected. Concerning the literature and the current results, some $\mathrm{NbC}(\mathrm{N})$ and $\mathrm{AlN}$ particles probably did not dissolve during sintering. The results of the EDS analysis agree with the precipitates visible on the SEM micrograph of the fracture of micro-alloyed PM steels (Alloys 2 and 4).

Past studies to characterize precipitation in microalloyed steels have been mainly carried out using the transmission electron microscopy (TEM) of extraction replicas and thin foils. ${ }^{47-50}$ However, quantitative chemical analysis is also helpful to determine the amounts of micro-alloying elements in solid solution and precipitates. Such investigations can be performed using a chemical or electrochemical procedure, selectively dissolving the steel matrix, and separating the undissolved particles from the matrix by filtration. ${ }^{51}$ Figure 7 shows the XRD precipitate peaks of the filter residue of Alloy 3 (Fe-0.25C-0.075Nb-0.075Al). The diffraction peaks in this Figure 7 match well with $\mathrm{NbC}(\mathrm{N})$ and AlN. Therefore, the precipitates rich in $\mathrm{Nb}$ and $\mathrm{Al}$ observed in Figure 7 correspond to these two types of precipitates.

In an alloy containing aluminium and without titanium or niobium, AlN precipitation occurs in the austenitic or ferritic regions. Several investigations report a

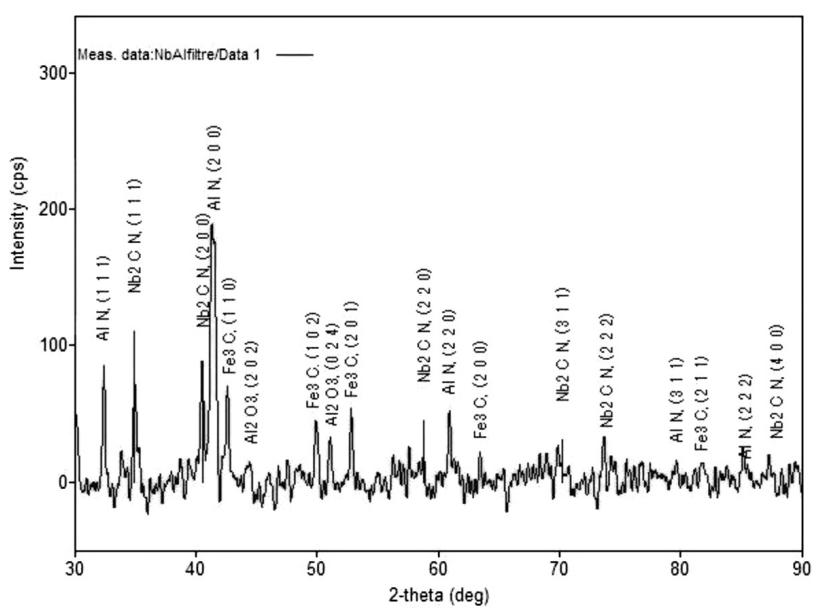

Figure 7: X-ray diffraction pattern of residues collected in the filter for Alloy 3

Slika 7: Rentgenogram ostankov zbranih na filtru pri zlitini 3 fine precipitation $(\ll 1 \mu \mathrm{m})$ with a large number density of nitride particles for steels containing between 29.96 $\mathrm{mg} / \mathrm{L}$ and $299 \mathrm{mg} /$ Lnitrogen. ${ }^{15}$ This precipitation is known to have significant effects upon recrystallization and austenite grain growth. ${ }^{52}$ The strengthening effect of $\mathrm{Nb}$ micro-alloying on steels also occurs with ferrite grain refinement due to austenite grain-boundary pinning, retardation of recrystallization and precipitation strengthening with an increase of the steel's strength. ${ }^{53}$

The elemental composition of the micro-alloyed powder metallurgy steels was performed using the X-ray fluorescence technique (XRF), which has many advantages: it is fast, accurate, non destructive and has a limit of detection in the range of few ppm for most elements. ${ }^{54}$ For these reasons, the XRF analysis method is widely used in many fields such as metallurgy, geology and mineralogy, the food industry and environmental management. However, most routine steel analyses involve standard wet-chemical methods or inductively coupled plasma atomic emission. These methods are destructive and require dissolution of the alloy and a long samplepreparation time. The use of the X-ray fluorescence technique is very attractive in many fields and especially for metal and alloy analyses. ${ }^{55}$ The sample preparation for XRF is relatively simple, so that it requires less time and work. For example, when the solid sample is homogeneous, then it only needs polishing to be ready for analysis. ${ }^{56}$ In this experimental work, micro-alloyed PM steels were analysed using the XRF technique to determine their elemental compositions. The chemical composition in $\%$ of mass fractions of Alloy 4 (Fe-0.25C$0.1 \mathrm{Nb}-0.1 \mathrm{Al})$ are presented in Table 5. It can be noted from Table 5 that most elemental compositions obtained conform to the values claimed by micro-alloyed steels.

Table 5: Chemical composition of Alloy 4 obtained by XRF analysis Tabela 5: Kemijska sestava zlitine 4, dobljene z XRF analizo

\begin{tabular}{|c|c|c|c|c|c|c|c|}
\hline No. & $\begin{array}{c}\text { Com- } \\
\text { ponent }\end{array}$ & Result & Unit & El. line & $\begin{array}{c}\text { Inten- } \\
\text { sity }\end{array}$ & $\begin{array}{c}w / \% \\
\text { normal }\end{array}$ & $\begin{array}{c}\text { Analyz- } \\
\text { ing } \\
\text { depth }\end{array}$ \\
\hline 1 & $\mathrm{Fe}$ & 99.0452 & $w / \%$ & & & 99.0452 & \\
\hline 2 & $\mathrm{C}$ & 0.2653 & $w / \%$ & $\mathrm{C}-\mathrm{KA}$ & 0.0400 & 0.2653 & \\
\hline 3 & $\mathrm{Mn}$ & 0.2223 & $w / \%$ & $\mathrm{Mn}-\mathrm{KA}$ & 0.7588 & 0.2223 & 0.0281 \\
\hline 4 & $\mathrm{Al}$ & 0.0974 & $w / \%$ & $\mathrm{Al}-\mathrm{KA}$ & 0.1224 & 0.0974 & 0.0009 \\
\hline 5 & $\mathrm{Nb}$ & 0.0918 & $w / \%$ & $\mathrm{Nb}-\mathrm{KA}$ & 1.1323 & 0.0918 & 0.0658 \\
\hline
\end{tabular}

Figure 8 shows the tensile-testing fracture surfaces of Alloy 1 and Alloy 3. The changes were observed on the fracture surface of the PM steel and micro-alloyed PM steels sintered at $1350{ }^{\circ} \mathrm{C}$ with respect to the microvoids' size, shape and depth. The mode of fracture for Alloy 1 (Figure 8a) is purely ductile. This is evident from the presence of numerous dimples along with fine and rounded pores. The mechanisms of the fracture were void formation and coalescence in the necks between adjoining fracturing microvolumes. Some microvoids pre-existed in the material, others nucleated and grew from defects or inclusions. The microvoids nucleate at strain discontinuities, such as those associated with 

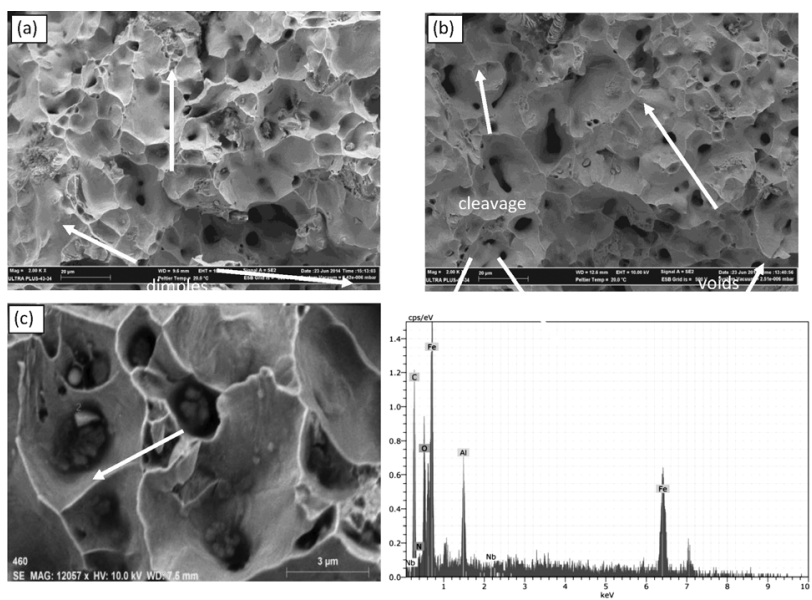

Figure 8: Fracture surfaces of: a) Alloy 1, b) Alloy 3 and c) EDS results from indicated particle of Alloy 3

Slika 8: Površine preloma: a) zlitina 1, b) zlitina 3 in c) EDS-analiza označenega delca $\mathrm{v}$ zlitini 3

a-priori defects (pores, microcracks), second-phase particles, inclusions, grain boundaries, dislocations pile-up. As the strain increases, the microvoids grow, coalesce, which involves plastic deformation, and eventually form a continuous fracture surface..$^{57}$

However, Alloy 3 showed dimples and cleavage facets (Figure 8b) indicating that the fracture is of the mixed type. Large voids were also observed in the alloy. These voids are an indication of the removal of $\mathrm{NbC}$ or AlN particulates in the minor fracture surfaces. The pull-out of the $\mathrm{NbC}$ or AlN particulates on the crack faces indicates a possible mechanism for crack-tip bridging in the micro-alloyed PM steel, as well M. Hajisafari et al. ${ }^{58}$ showed that void nucleation and growth in micro-alloyed steel are a function of the shape factor of second-phase particles and the mismatch between the second-phase particle and the metal matrix. Voids firstly nucleate around second-phase particles and consequently grow.

The Al-N-based particle inside the large microvoids of micro-alloyed PM steel is clearly shown in the SEM fractograph and the corresponding EDS results in Figure 8c. M. A. Erden et al. ${ }^{32}$ investigated the tensile behaviour of sinter-forged Ti-alloyed PM steel and they observed a mixed (ductile-brittle) type of fracture in the microalloyed PM steel with Ti due to the formation of carbides and the carbide pull-off during heavy deformation.

\section{CONCLUSIONS}

Micro-alloyed PM steels with three different volume fractions of $\mathrm{Nb}-\mathrm{Al}$ were processed through cold pressing and sintering in an argon atmosphere. The important findings obtained can be summarised as follows:

Micro-alloyed PM steels were analysed using the XRF technique to determine their elemental compositions. The results show that most elemental compositions obtained confirm to the values claimed by micro-alloyed steels.
Micro-alloying with $\mathrm{Nb}$ and $\mathrm{Al}$ requires high-temperature sintering to dissolve the $\mathrm{Nb}$ and $\mathrm{Al}$ in the austenite. The relative density of the sintered $\mathrm{Nb}-\mathrm{Al}$ micro-alloyed PM steels can reach $94 \%$ after sintering at $1350{ }^{\circ} \mathrm{C}$.

The addition of $\mathrm{Nb}-\mathrm{Al}$ can improve the strength of micro-alloyed PM steel through precipitation hardening and microstructure refining. The $\mathrm{NbC}(\mathrm{N})$ and $\mathrm{AlN}$ precipitates inhibit the grain growth during the sintering step, leading to enhanced strength.

The EDS and XRD analyses of the micro-alloyed PM steels revealed $\mathrm{Nb}$ - and Al-rich particles in microalloyed PM steel. The presence of $\mathrm{Nb}$ and $\mathrm{Al}$ elements in the particles indicates that $\mathrm{NbC}(\mathrm{N})$ and $\mathrm{AlN}$ formed during sintering and/or precipitate during the cooling after sintering.

The analysis of the fracture surface indicated that PM steel without micro-alloying addition exhibited ductile fracture. In the case of the micro-alloyed PM steels the mode of fracture is the mixed type with ductile and brittle regions. This could be attributed to the pull-out of $\mathrm{NbC}$ or AlN particles during deformation, indicating the possible mechanism for crack tip is bridging in the micro-alloyed PM steels.

\section{Acknowledgements}

The authors gratefully acknowledge financial support from TÜBITTAK, the Research Project of The Scientific and Technological Research Council of Turkey with the NO: $113 \mathrm{M} 350$.

\section{REFERENCES}

${ }^{1}$ Y. Li, D. N. Crowther, P. S. Mitchell, T. N. Baker, The Evolution of Microstructure during Thin Slab Direct Rolling Processing in Vanadium Microalloyed Steels, ISIJ International, 42 (2002) 6, 636-644, doi:10.2355/isijinternational.42.636

${ }^{2}$ B. A. Graville, Proc. Int. Conf. Welding of HSLA Structure Steels ASM, Metals Park, Ohio 1978, 85-101

${ }^{3}$ M. Olasolo, P. Uranga, J. M. Rodriguez-Ibabe, B. López, Effect of austenite microstructure and cooling rate on transformation characteristics in a low carbon $\mathrm{Nb}-\mathrm{V}$ microalloyed steel, Mater. Sci. Eng. A, 528 (2011) 6, 2559-2569, doi:10.1016/j.msea.2010.11.078

${ }^{4}$ A. M. Sage, HSLA Steels: Processing, Properties and Applications, G. Tither, Z. Shouhua (Eds.), 1992, 51-61

${ }^{5}$ G. Y. Qiao, F. R. Xiao, X. B. Zhang, Y. B. Cao, B. Liao, Effects of contents of $\mathrm{Nb}$ and $\mathrm{C}$ on hot deformation behaviors of high $\mathrm{Nb}$ X80 pipeline steels, Trans. Nonferrous Met. Soc., 19 (2009) 6, 1395-1399, doi:10.1016/S1003-6326(09)60039-X

${ }^{6}$ J. C. Cao, Q. Y. Liu, Q. L. Yong, X. J. Sun, Effect of Niobium on Isothermal Transformation of Austenite to Ferrite in HSLA Low-Carbon Steel, J.Iron and Steel Res. Int., 14 (2007) 3, 52-56, doi:10.1016/S1006-706X(07)60043-0

${ }^{7}$ E. J. Palmiere, C. I. Garcia, A. J. DeArdo, Compositional and microstructural changes which attend reheating and grain coarsening in steels containing niobium, Mater. Metall. Trans. A, 25A (1994) 2, 277-286, doi:10.1007/BF02647973

${ }^{8}$ S. Vervynckt, K. Verbeken, P. Thibaux, Y. Houbaert, Recrystallization-precipitation interaction during austenite hot deformation of a $\mathrm{Nb}$ microalloyed steel, Mater. Sci. Eng. A, 528 (2011) 16-17, 5519-5528, doi:10.1016/j.msea.2011.03.087 
${ }^{9}$ T. Siwecki, Modelling of Microstructure Evolution during Recrystallization Controlled Rolling, ISIJ Int., 32 (1992) 3, 368-376, doi:10.2355/isijinternational.32.368

${ }^{10}$ M. G. Mecozzi, J. Sietsma, S. Van der Zwaag, Analysis of $\gamma \rightarrow \alpha$ transformation in a $\mathrm{Nb}$ micro-alloyed $\mathrm{C}-\mathrm{Mn}$ steel by phase field modelling, Acta. Mater., 54 (2006) 5, 1431-1440, doi:10.1016/ j.actamat.2005.11.014

${ }^{11}$ M. Gómez, S. F. Medina, A. Quispe, P. Valles, Static Recrystallization and Induced Precipitation in a Low Nb Microalloyed SteeI, SIJ Int., 42 (2002) 4, 423-431, doi:10.2355/isijinternational.42.423

${ }^{12}$ T. Gladman, The Physical Metallurgy of Microalloyed Steels, The institute of Materials, London, 1997, 102-104

${ }^{13}$ G. Jeanmaire, M. Dehmas, A. Redjaïmia, S. Puech, G. Fribourg, Precipitation of aluminum nitride in a high strength maraging steel with low nitrogen content, Mater. Charac., 98 (2014) 4, 193-201, doi:10.1016/j.matchar.2014.11.001

${ }^{14}$ L. M. Cheng, E. B. Hawbolt, T. R. Meadowcroft, Dissolution and Coarsening oF Aluminum Nitride Precipitates in Low Carbon Steel Distribution, Size and Morphology, Can. Metall. Q., 39 (2000), 73-85, doi:10.1179/000844300794388930

${ }^{15}$ R. Radis, E. Kozeschnik, Kinetics of AlN precipitation in microalloyed steel, Model Simul. Mater. Sci. Eng., 18 (2010) 5, 605-611, doi:10.1088/0965-0393/18/5/055003

${ }^{16}$ C. Schade, T. Murphy, A. Lawley, R. Doherty, Int. J. of Powder Metall., 48 (2012) 3, 51-59

${ }^{17}$ R. Chandramouli, T. K. Kandavel, D. Shanmugasundaram, T. Ashok Kumar, Deformation, densification, and corrosion studies of sintered powder metallurgy plain carbon steel preforms, Mater. Des., 28 (2007), 2260-2264, doi:10.1016/j.matdes.2006.05.018

${ }^{18}$ W. B. Morrison, The Proceedings of the Vanitec Symposium Guilin, China 2000, 25-35

${ }^{19}$ ASTM E8/E8M, Standard Test Methods for Tension Testing of Metallic Materials, ASTM International, West Conshohocken, PA 2013

${ }^{20}$ ASTM B328-96, Standard Test Method for Density, Oil Content, and Interconnected Porosity of Sintered Metal Structural Parts and Oil-Impregnated Bearings, ASTM International, Philadelphia, USA 2004

${ }^{21}$ S. Sankaran, S. Sangal, K. A. Padmanabhan, Microstructural evolution and tensile behaviour of medium carbon microalloyed steel processed through two thermomechanical routes, Mater. Sci. Technol., 21 (2005) 10, 1152-1160, doi:10.1179/174328405X51767

${ }^{22}$ Y. Pu, B. Guo, J. Zhou, S. Zhang, H. Zhou, J. Chen, Microstructure and tribological properties of in situ synthesized $\mathrm{TiC}$, $\mathrm{TiN}$, and $\mathrm{SiC}$ reinforced $\mathrm{Ti} 3 \mathrm{Al}$ intermetallic matrix composite coatings on pure $\mathrm{Ti}$ by laser cladding, Appl. Surf. Sci., 255 (2008) 5, 2697-203, doi:10.1016/j.apsusc.2008.07.180

${ }^{23}$ J. R. Blank, T. Gladman, Quantitative Metallography, Tools and Technique in Physical Metallurgy, F. Weinberg, M. Dekker (Eds.), New York 1970, 265-327

${ }^{24}$ S. Gündüz, A. Çapar, Influence of forging and cooling rate on microstructure and properties of medium carbon microalloy forging steel, J. of Mater Sci Letters, 41 (2006) 2, 561-564, doi:10.1007/ s10853-005-4239-y

${ }^{25}$ A. M. Sage, HSLA Steels: Processing, Properties and Applications, G. Tither, Z. Shouhua (Eds.), 1992, 51-61

${ }^{26}$ T. Gladman, J. Woodhead, J. of Iron and Steel Inst., 194 (1960), 189-193

${ }^{27}$ C. Schade, T. Murphy, A. Lawley, R. Doherty, Int. J. of Powder Metall., 48 (2012) 6, 41-48

${ }^{28}$ S. S. Campos, H. J. Kestenbach, E. V. Morales, On strengthening mechanisms in commercial Nb-Ti hot strip steels, Metall. Mater Trans. A, 32 (2001), 1245-1248, doi:10.1007/s11661-001-0133-7

${ }^{29}$ B. Dutta, C. M.Sellars, Mater. Sci. Technol., 2 (1986) 2, 146-153

${ }^{30}$ J. G. Jung, J. S. Park, J. Kim, Y. K. Lee, Carbide precipitation kinetics in austenite of a $\mathrm{Nb}-\mathrm{Ti}-\mathrm{V}$ microalloyed steel, Mater. Sci. Eng. A., 528 (2011) 16, 5529-5535, doi:10.1016/j.msea.2011.03.086
${ }^{31}$ H. Karabulut, S. Gündüz, Effect of vanadium content on dynamic strain ageing in microalloyed medium carbon steel, Mater. Des., 25 (2004), 521-527, doi:10.1016/j.matdes.2004.01.005

${ }^{32}$ M. A. Erden, S. Gündüz, M. Türkmen, H. Karabulut, Microstructural characterization and mechanical properties of microalloyed powder metallurgy steels, Mater. Sci. Eng. A., 616 (2014), 201-206, doi:10.1016/j.msea.2014.08.026

${ }^{33}$ D. T. Llewellyn, R. C. Hudd, Steels: Metallurgy and Applications, Reed Educational and Professional Publishing Ltd, Oxford 1998, $153-154$

${ }^{34}$ L. C. Cuddy, J. C. Raley, Metall. Trans. A., 14 (1983) 10, 1989-1995

${ }^{35}$ T. Gladman, The Minerals, G. Tither, Z. Shouhua (Eds.), Metals and Materials Society, (1992) 3, 267-271

${ }^{36}$ K. Narita, Transact ISIJ, 15 (1975), 145-152

${ }^{37}$ E. O. Hall, Process Physical Society, 64B (1951), 747-755

${ }^{38}$ N. J. Petch, J. Iron and Steel Inst., 174 (1953), 25-28

${ }^{39}$ F. B. Pickering, T. Gladman, Iron and Steel Inst, Special Report No: 81, (1963), 10-20

${ }^{40}$ R. Oberacker, F. Thummler, Metal Powder Report, 44 (1989), $120-124$

${ }^{41}$ R. Oberacker, F. Thummler, Proceedings of the International Powder Metallurgy Conference, 1986, 647-648

${ }^{42}$ M. Orban, R. L. Orban, Sintered Structural Cu-Ni-Mo-C Low Alloyed Steels with Small Niobium Additions, Mater. Sci. Forum, 534 (2007), 725-728, doi:10.4028/www.scientific.net/MSF.534-536. 725

${ }^{43}$ T. Tsutsui, K. Ishii, M. Yoshida, Proceedings of the Powder Metallurgy World Congress, 2 (1994) 1, 883-886

${ }^{44}$ G. Jeanmaire, M. Dehmas, A. Redjaïmia, S. Puech, G. Fribourg, Mater. Charac., 98 (2014), 193-201

${ }^{45}$ F. Changnon, Y. Trudel, International Conference on Powder Metallurgy \& Particulate Material, Las Vegas, Nevada 1998, 1-8

${ }^{46}$ A. Bergmark, L. Alzati, Fatigue crack path in Cu-Ni-Mo alloyed PM steel, Fatigue Fract. Eng. Mater. Struct., 28 (2005), 229-235, doi:10.1111/j.1460-2695.2004.00841.x

${ }^{47}$ A. L. Rivas, D. M. Michal, M. E. Burnett, C. F. Musolff, Collection Papers $2^{\text {nd }}$ Int. Symp. Microalloyed Bar and Forging Steels, C. J. Van Tyne, G. Krauss, D. K. Matlock (Eds.), The Minerals, Metals \& Materials Society, Golden, Colorado, U.S.A. 1996, 159-172

${ }^{48}$ H. J. Kestenbach, E. V. Morales, Acta Microsc., 7 (1998), 22-33

${ }^{49}$ R. F. Morais, A. Reguly, L. H. de Almeida, Transmission Electron Microscopy Characterization of a $\mathrm{Nb}$ Microalloyed Steel for Carburizing at High Temperatures, J. Mater. Eng. Perform, 15 (2006) 4, 494-498, doi:10.1361/105994906X124596

${ }^{50}$ J. Strid, K. E. Easterling, Acta Metal., 33 (1985), 2057-2074

${ }^{51}$ A. L. Rivas, E. Vidal, D. K. Matlock, J. G. Speer, Electrochemical extraction of microalloy carbides in Nb-steel, Revista De Metalurgia, 44 (2008), 447-456, doi:10.3989/revmetalm.0771

${ }^{52}$ K. J. Irvine, F. B. Pickering, J. Iron Steel Inst., 201 (1963), 944-959

${ }^{53}$ A. G Kostryzhev, A. Al Shahrani, C. Zhu, J. M. Cairney, S. P. Ringer, C. R. Killmore et al., Effect of niobium clustering and precipitation on strength of an NbTi-microalloyed ferritic steel, Mater. Sci. Eng. A, 607 (2014), 226-235, doi:10.1016/j.msea.2014.03.140

${ }^{54}$ M. A. Al-Eshaikh, A. Kadachi, Proceedings of the $12^{\text {th }}$ International Conference on Machine Design and Protection, Kusadasi, Turkey 2006

${ }^{55}$ G. J. Steven, S. L. Dale, Adv. X-ray Anal, 45 (2002), 457-463

${ }^{56}$ M. A. Al-Eshaikh, A. Kadachi, Elemental analysis of steel products using X-ray fluorescence (XRF) technique, J. of King Saud UniEngi Sci., 23 (2011) 2, 75-79, doi:10.1016/j.jksues.2011.03.002

${ }^{57}$ E. Dudrová, M. Kabátová, Powder Metall Prog, 8 (2008) 2, 59-75

${ }^{58}$ M. Hajisafari, S. Nategh, H. Yoozbashizadeh, A. Ekrami, Fatigue Properties of Heat-Treated 30MSV6 Vanadium Microalloyed Steel, J. Iron and Steel Res. Int., 20 (2013) 5, 66-73, doi:10.1007/s11665012-0324-y 